\title{
ADVANCES IN MULTI-PHOTON PROCESSES AND SPECTROSCOPY
}


This page is intentionally left blank 


\section{ADVANCES IN MULTI-PHOTON PROCESSES AND SPECTROSCOPY}

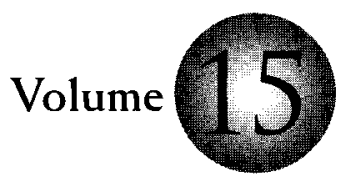

Edited by

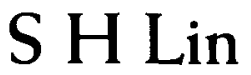

Institute of Atomic and Molecular Sciences,

TAIWAN \& Arizona State University, USA

\section{A A Villaeys}

Institut de Physique et Chimie des

Matériaux de Strasbourg, FRANCE

\section{Y Fujimura}

Graduate School of Science

Tohoku University, JAPAN 


\section{Published by}

World Scientific Publishing Co. Pte. Ltd.

P O Box 128, Farrer Road, Singapore 912805

USA office: Suite 1B, 1060 Main Street, River Edge, NJ 07661

UK office: 57 Shelton Street, Covent Garden, London WC2H 9HE

\section{British Library Cataloguing-in-Publication Data}

A catalogue record for this book is available from the British Library.

\section{ADVANCES IN MULTI-PHOTON PROCESSES AND SPECTROSCOPY - Vol. 15}

Copyright $(1) 2003$ by World Scientific Publishing Co. Pte. Ltd.

All rights reserved. This book, or parts thereof, may not be reproduced in any form or by any means, electronic or mechanical, including photocopying, recording or any information storage and retrieval system now known or to be invented, without written permission from the Publisher.

For photocopying of material in this volume, please pay a copying fee through the Copyright Clearance Center, Inc., 222 Rosewood Drive, Danvers, MA 01923, USA. In this case permission to photocopy is not required from the publisher.

ISBN $981-238-263-1$

This book is printed on acid-free paper.

Printed in Singapore by Mainland Press 


\section{Preface}

In view of the rapid growth in both experimental and theoretical studies of multiphoton process and multiphoton spectroscopy of atoms, ions and molecules in chemistry, physics, biology, materials science, etc., it is desirable to publish an Advanced Series that contains review papers readable not only by active researchers in these areas, but also by those who are not experts in the field but who intend to enter the field. The present series attempts to serve this purpose. Each review article is written in a self-contained manner by the experts in the area so that the readers can grasp the knowledge in the area without too much preparation.

The topics covered in this volume are "Polarizabilities and Hyperpolarizabilities of Dendritic Systems", "Molecules in Intense Laser Fields: Nonlinear Multiphoton Spectroscopy and Near-Femtosecond To Sub-Femtosecond (Attosecond) Dynamics", and "Ultrafast Dynamics and non-Markovian Processes in Four-Photon Spectroscopy". The editors wish to thank the authors for their important contributions. It is hoped that the collection of topics in this volume will be useful not only to active researchers but also to other scientists in biology, chemistry, materials science and physics.

S. H. Lin
A. A. Villaeys
Y. Fujimura 
This page is intentionally left blank 


\section{Contents}

Preface $\quad$ V

Part One: Polarizabilities and Hyperpolarizabilities of

Dendritic Systems ................................................ 1

Masayoshi Nakano and Kizashi Yamaguchi

Part Two: $\quad$ Molecules in Intense Laser Fields: Nonlinear

Multiphoton Spectroscopy and Near-Femtosecond

To Sub-Femtosecond (Attosecond) Dynamics.......... 147

André D. Bandrauk and Hirohiko Kono

Part Three: Ultrafast Dynamics and non-Markovian

Processes in Four-Photon Spectroscopy

B. D. Fainberg 